\title{
Eurostudia
}

\section{Bounding Institutional Authority in Comparative Politics and International Relations}

\section{John Leslie et Anne L. Clunan}

Volume 7, numéro 1-2, 2011

Deutschland und Europa : Grenzen und Grenzgänge(r)

L'Allemagne et l'Europe : frontières et passeurs

URI : https://id.erudit.org/iderudit/1015015ar

DOI : https://doi.org/10.7202/1015015ar

Aller au sommaire du numéro

Éditeur(s)

Le Centre canadien d'études allemandes et européennes

ISSN

1718-8946 (numérique)

Découvrir la revue

Citer cet article

Leslie, J. \& Clunan, A. L. (2011). Bounding Institutional Authority in

Comparative Politics and International Relations. Eurostudia, 7(1-2), 119-131.

https://doi.org/10.7202/1015015ar

Tous droits réservés $@$ Le Centre canadien d'études allemandes et européennes, 2012
Ce document est protégé par la loi sur le droit d'auteur. L'utilisation des services d'Érudit (y compris la reproduction) est assujettie à sa politique d'utilisation que vous pouvez consulter en ligne.

https://apropos.erudit.org/fr/usagers/politique-dutilisation/ 
John Leslie

Victoria University of Wellington

Anne L. Clunan

Naval Postgraduate School, Monterey, CA

$\mathrm{T}$ This paper seeks to draw attention to a neglected but essential element of institutions: their boundaries. ${ }^{1}$ Boundaries permit actors to organize the world around them into categories and groups and to establish arenas of authority or jurisdiction. Scholars too often assume that boundaries between groups are firm and clear, and assume that these distinctions form the basis for social hierarchies and divisions of labor. ${ }^{2}$ However, the nature of boundaries is no less important to institutional operation and social organization than is the fact of their existence. As the first step in a larger research program, we set out to elaborate here not only the importance that the existence of boundaries has in creating and regulating social organization, but also the political significance that the varying nature of boundaries has. We draw on our own work from very different sub-disciplines of political science to highlight what boundaries do and how they vary, as well as to raise a set of theoretical questions to guide further investigation.

Our interest in institutional boundaries arose from puzzles arising out of our research. One of us has focused on political parties, and found that despite similar structural conditions, actors responded by creating very different boundaries between political parties and labor unions. The other one of us focuses on international institutional change, and realized that IR theorists' ability to understand and explain such change largely centers on how they conceptualize the boundaries of key institutions, in particular those of the sovereign state. What we present here is our first effort at laying out the rationale for an investigation of institutional boundaries. We view this paper as the initial step in developing a research program that examines how and why boundaries matter as well as how they arise and change. We

\footnotetext{
${ }_{1}^{1}$ The views expressed in this document are those of the authors and do not represent the official position of the Department of Defense or the U.S. government.

${ }^{2}$ Explanations of nationalism such as those of Karl W. Deutsch, Nationalism and Social Communication, $2^{\text {nd }}$ ed. (Cambridge, MA: MIT Press, 1966); Ernst Gellner, Nations and Nationalism (Ithaca, NY: Cornell University Press, 1983); Ernst Haas, Nationalism, Liberalism and Progress (Ithaca, NY: Cornell University Press, 1997); Benedict Anderson, Imagined Communities (London: Verso, 1983) are obvious exceptions to this.
} 
conclude by asking whether the nature of boundaries substantially affects the mechanisms of institutional change that are likely to operate.

We believe that a study of boundaries can aid institutional analysis in a number of ways. First, institutional analyses have emphasized how institutions create relations of authority; we hope to demonstrate that the bounds of authority, or jurisdiction, are as important to understanding political outcomes. Second, like relations of authority, boundaries or jurisdictions reflect the circumstances in which they are created. As a consequence, boundaries will vary in politically significant ways. We believe that a critical dimension on which boundaries vary is in their permeability. Finally, we propose as subject for further research that this variance is most likely related to particular types of institutional change.

We proceed first to discuss how the literature on institutions has neglected the question of boundaries. We suggest that this neglect has shaped current institutionalist accounts of institutional reproduction and change, institutional stability or durability, as well as institutional capacity to shape actors' behavior. We develop in greater depth how our proposed attention to boundaries can yield a better understanding of institutional reproduction and institutional capacity, as well as institutional change.

\section{THE NEW INSTITUTIONALISMS AND INSTITUTIONAL BORDERS}

The new institutionalisms have focused on the authority relations that institutions create rather than their boundaries. Consider, for example, two well-known definitions of institutions from international relations and comparative political economy. Stephen Krasner defines institutions, or - more accurately - “international regimes," as "sets of implicit or explicit principles, norms, rules, and decision-making procedures around which actors' expectations converge in a given area of international relations." 3 Peter Hall refers to them as "the formal rules, compliance procedures, and standard operating practices that structure the relationship between individuals in various units of the polity and economy." ${ }^{4}$ Both authors emphasize the authoritative and hierarchical aspects of institutions rather than the limits of institutions' authority, or jurisdiction. For Krasner, regimes are bounded by a group of actors' expectations and an issue area. Hall leaves institutional boundaries even less well-defined, as "various units." This neglect of the limits that boundaries place on the authority relations inside institutions represents a significant gap in these literatures and in our understanding of institutions. Institutions are embedded in "societies" ${ }^{5}$ with other institutions and, because actors navigate not only within

\footnotetext{
${ }^{3}$ Steven Krasner, "Structural Causes and Regime Consequences: Regimes as Intervening Variable," in International Regimes, ed. Stephen Krasner (Ithaca, NY: Cornell University Press, 1983), 2.

${ }^{4}$ Peter Hall, Governing the Economy (New York and Oxford: Oxford University Press, 1986), 19.

${ }^{5}$ Note that "society" and "social" refer to particular groupings of actors. "Society" can refer to the community of individuals bounded by a state or it can refer to the anarchical "society" of nation
} 
institutions but also between them, it is important to understand not only how the "rules of the game" work, but also how far they extend. ${ }^{6}$ By recognizing that institutions create not only authority relations but also "jurisdictions" we can increase our understanding of how institutions come into being, how they reproduce themselves, and how they shape the behavior of actors.

\section{INSTITUTION BOUNDARIES AND INSTITUTIONAL ORIGINS}

The recognition that institutions not only create authority relations but also bound those relations entails the recognition that institutions are a product of forces in tension. Institutions are simultaneously the product of cooperation and conflict, an outcome that traditional perspectives do not permit. Traditional approaches to group formation have tended to emphasize the role of either cooperation or conflict, but not their union. For example, pluralists and rationalists of various bents observe that individuals form groups and institutions to pursue common interests. ${ }^{7}$ From this perspective, cooperation is limited only by the bounds of rationality and the boundaries of groups and institutions can expand, potentially, without limit. Traditional structuralists, on the other hand, argue that structure limits cooperation and that conflict is central to institutional construction. They argue that real cleavages divide societies and create boundaries across which cooperation and voluntary institutions do not extend. For Marxists, boundaries that parallel class divisions are real, while those that separate organizations on either side of a social divide are transitory. ${ }^{8}$ Structural realists in international relations recognize the explanatory power of states and the borders between them, but not of institutions that cross state boundaries or exist wholly within them. ${ }^{9}$ These two perspectives view social organization differently, one as the reflection of interest and the other as the reflection of power. There is either harmony or conflict but little room for strategic interaction in organizing societies.

The new institutionalisms arose to explain cooperation in circumstances where there is strategic interaction, but cooperation is problematic. ${ }^{10}$ Even while they recognize the complexities imposed by strategic interaction, however, new institutionalists neglect boundaries, causing them to limit their understanding of the forms of

states. Hedley Bull, The Anarchical Society (New York: Columbia University Press, 1977).

6 Mark Granovetter, "Economic Action and Social Structure: The Problem of Embeddedness," American Journal of Sociology 91 (1985): 481-510.

${ }^{7}$ David B. Truman, The Governmental Process (New York: Alfred A. Knopf, 1963); Robert Keohane, After Hegemony (Princeton, NJ: Princeton University Press, 1984).

${ }^{8}$ Ira Katznelson, "Working-Class Formation: Constructing Cases and Comparisons," in Working-Class Formation, eds. Ira Katznelson and Aristide Zolberg (Princeton, NJ: Princeton University Press, 1986), 3-41.

${ }^{9}$ Kenneth Waltz, Theory of International Politics (Reading, MA: Addison-Wesley Publishing Company, 1979).

10 Douglass North, Institutions, Institutional Change, and Economic Performance (Cambridge, UK: Cambridge University Press, 1990), 16. 
cooperation. The central problem for the new institutionalisms was how to explain cooperation among actors with common interests but different preferences. For rational choice institutionalists, conflict is a dysfunctional consequence of information asymmetries, transaction costs, and coordination problems that institutions permit actors to overcome. It is assumed that a universal definition of rationality or utility bridges these conflicts, potentially extending boundaries of institutions out infinitely. Clever institutional designers, it is implied, can always find the common ground and manage conflicts.

Historical institutionalists bring structure and conflict back into the spotlight in institutional construction, but they offer a truncated set of options for the institutional management of conflict. They recognize that institutional construction is embedded in social structures that generate ideas and interests as well as constraints on resources and power. However, they confine the influence of structure and conflict to the construction of an institution's authority relations. Structure, conflict, and power ultimately determine whose preferences are favored by authoritative rules, but they ignore the possibility that actors may decide to limit institutional jurisdiction, leaving some actors or actions beyond the reach of its authority relations. They may create parallel sets of authoritative rules and then seek to regulate their interactions. This is not quite cooperation, nor is it conflict, but rather an "agreement to disagree" or "peaceful coexistence."11 The institutional nature of such arrangements becomes apparent, however, only when one focuses on boundaries.

Recognition that institutional construction is socially embedded points to the dual role that boundaries play "inside" and "outside" institutions and the "critical" nature of the junctures in which they are often created. They designate who may, or must, conform to rules defining authority "within" an institution. But they also demarcate the extent of those rules and how one institution, and its members, interact with other institutions. Defining such relations is critical not only to the institution's own survival but also to the survival of other institutions and, perhaps, the survival of society. ${ }^{12}$ This interdependence points to the fact that the boundaries of important institutions are likely to crystallize at the same time and as part of a larger process. Actors reach "settlements" that create full-fledged cooperation in some institutions even as they embed conflicting values in other institutions that exist parallel to one another. In establishing one area of authority and jurisdiction

\footnotetext{
${ }^{11}$ Günther Roth, The Social Democrats in Imperial Germany (New York: Arno Press, 1979) describes the "negative integration" of Social Democrats in Wilhelmine Germany. This issue is also central to literature on "consociationalism." See for example Arend Lijphart, Democracy in Plural Societies (New Haven and London: Yale University Press, 1977) and Kurt Richard Luther, "A Framework for the Comparative Analysis of Political Parties and Party Systems in Consociational Democracy," in Party Elites in Divided Societies, eds. Kurt Richard Luther and Kris Deschouwer (London: Routledge, 1999).

${ }^{12}$ This has been the focus of the population ecology school in organizational theory. See Michael T. Hannan and John Freeman, "The Ecology of Organizational Founding: American Labor Unions, 18361985," The American Journal of Sociology 92 (1987): 910-943.
} 
where certain actors have specified powers and roles, boundaries also create the negative of the institution in establishing realms where such authority, jurisdiction, powers and roles do not apply. ${ }^{13}$ Subsequently, institutional boundaries regulate the limits of institutional authority and the conduct of institutional interactions.

\section{BOUNDARIES, SOCIAL ORDER, AND INSTITUTIONAL SURVIVAL}

The dual role of boundaries points to a source of legitimacy and support for institutions that institutionalists have neglected. For rational choice and historical institutionalists, institutions thrive when they reproduce and extend the interests they were constructed to promote directly. ${ }^{14}$ From this perspective, it is the interests of actors organized within the institution or the interests of groups or other institutions that deal directly with it that support its survival. For economic institutionalists, actors will seek to design institutional boundaries so as to economize on transactions costs. They do not investigate how the social environment or "background conditions" form and implicate the drawing of boundaries. ${ }^{15}$ Historical institutionalists tell us how the institutions come into being and how their boundaries may differ, but tell us little about how these boundaries reinforce or undermine the existing social order. Institutions contribute to the reproduction of societal values and social stability generally. Because they transmit values from the level of society to the level of individual actors, institutions are important to the reproduction of the values around which societies are organized. But the embeddedness of institutions in a society and the dual role of their boundaries point to a far broader base of support.

Institutional boundaries do a number of things: they protect the institution; they provide institutional continuity; they define who belongs to the institution; they establish rights of institutions, placing them in particular positions vis-à-vis each other within a society; and they constrain actors' behavior across and within institutions. As such, it is the boundaries of institutions that make social order possible. ${ }^{16}$ Boundaries are established to shield institutions from external pressures and influences as much as to create internal authority relations. They help ensure institutional survival because they provide a measure of security and a legal basis on which to challenge incursions and violations. ${ }^{17}$ Sovereignty functions in this manner at the international level, helping to ensure the survival of weak states. ${ }^{18}$ In the United States, the boundaries of non-profit status allow 501(c)(3) organizations to guard

\footnotetext{
${ }^{13}$ One might think of the "pillar" structure of the European Union from the Maastricht Treaty to the Lisbon Treaty as a particularly transparent example.

${ }_{14}$ Paul Pierson, "Increasing Returns, Path Dependence, and the Study of Politics," American Political Science Review 94 (2000): 251-268.

${ }^{15}$ W. Richard Scott, Institutions and Organizations, $2^{\text {nd }}$ edn. (Thousand Oaks, CA: Sage, 2001), 103.

${ }^{16}$ K. J. Holsti, Taming the Sovereigns: Institutional Change in International Politics (Cambridge: Cambridge University Press, 2004), 116-118.

${ }^{17}$ Holsti, Taming the Sovereigns, 116-117.

${ }_{18}$ Robert H. Jackson, Quasi-States: Sovereignty, International Relations and the Third World (Cambridge: Cambridge University Press, 1990); and Holsti, Taming the Sovereigns.
} 
against their take-over by potentially more powerful political interests, serving thereby to enable institutional survival as well as broader social goals of public interest. Boundaries also help to guarantee institutional continuity, by designating the institution rather than actors within it as the carriers of autonomy. Political parties continue to exist despite changes in leadership and states survive when governments change or are not recognized. ${ }^{19}$

Institutional boundaries encourage social order by determining whether and how institutions "fit" into the "societies" of which they are part. In short, boundaries define how settlements regulating conflicts and cooperation within an institution conform to broader patterns of conflict and cooperation that define "societies." 20 They organize the myriad institutions within a social space. They place an institution and its rules in superordinate, subordinate, and competitive relationships with other institutions and groups and they transmit these relations to the level of individuals. In doing so, they establish particular roles and rights both within, and between, institutions and societies. ${ }^{21}$ For example, a basic institution of international society is diplomatic immunity, which designates the person, property, residence and embassy of a foreign ambassador as falling not within the jurisdiction of the host country, but rather the home country. To belong to international society, sovereigns must accept that within their territory there are bounded areas and actors outside of their authority and control. The boundaries of this institution are clearly specified and are designed to preserve the overarching institution of sovereign equality. ${ }^{22}$ When such institutional boundaries are violated, as when the revolutionary Iranian government held US and Canadian diplomats hostage in the 1979-1980 hostage crisis, the violator is viewed as not belonging to international society and is often punished.

Rules defining boundaries bring individuals in line with the decision-making mechanisms that make collective action possible within the institution. ${ }^{23}$ At the same

\footnotetext{
${ }^{19}$ Holsti, Taming the Sovereigns, 117.

${ }^{20}$ March and Olsen distinguish between two different logics at work in much of international relations theorizing, a logic of consequences and a logic of appropriateness. Most structuralists and pluralists and rationalists adhere to the logic of consequences - that the ends produced explain the means pursued, or in our case, the boundaries built. However, we argue that boundaries are defined not only according to the consequences, but they also reflect and create logics of appropriateness. James G. March and Johan P. Olsen, "The Institutional Dynamics of International Political Orders," International Organization 52 (1998): 943-69.

${ }^{21}$ March and Olsen, "Institutional Dynamics."

${ }^{22}$ The institutions of diplomacy were spelled out in the Vienna Convention on Diplomatic Relations, which entered into force in 1964, but which codified five centuries of practice. The International Court of Justice ruled in 1980 that the Iranian government had violated not only a contract in the form of the Vienna Convention, but also the broader obligations of a state in international society. See Ian Brownlie, Principles of International Law $6^{\text {th }}$ ed. (Oxford: Oxford University Press, 2003), 342. On diplomacy as one of the fundamental institutions giving rise to an international society of states, see Hedley Bull, The Anarchical Society, ch. 3.

${ }^{23}$ Ira Katznelson, "Periodization and Preferences: Reflections on Purposive Action in Comparative Historical Social Science," in Comparative Historical Analysis in the Social Sciences, eds. James Mahoney
} 
time, they force individual behavior to conform to rules governing relationships between one institution and others. They provide authoritative rules about behavior that tell individuals how to navigate complex social environments where groups and institutions pursue different preferences. ${ }^{24}$ The government of Iran was cast out by international society for failing to prevent and then approving the actions of militant students, not government officials, which were contrary to international society's values of maintaining inter-state interaction and the inviolability of sovereigns. Iran was punished for not forcing its individual citizens to conform to the rules governing relations among states within international society. While Iran continues to pursue values at odds with many other states, it no longer pursues behaviors that directly challenge the core values of an international society of sovereign states. ${ }^{25}$

Boundaries in the German Union Federation's (DGB) have evolved to place similar constraints on the behavior of German unionists. Article 8 of the DGB's postwar statute mandated "neutrality," obligating the federation and its unions to operate independently of the influence from government, parties, religious communities, public administrations and employers, although the exact meaning of union "independence" -initially-remained ambiguous. ${ }^{26}$ In the first years of the Federal Republic the conservative government of Chancellor Konrad Adenauer resisted successfully DGB attempts to influence directly government policy. Social Democratic unionists responded by purging the DGB leadership and mobilizing the union movement to support the Social Democratic Party (SPD) in the 1953 federal elections. ${ }^{27}$ In turn, Catholic and Christian unionists threatened to desert the DGB and found a rival Christian federation. Unwilling to reactivate the ideological schisms of Weimar era unions, Social Democratic unionists backed down and the DGB placed clear boundaries on the use of union resources for political campaigns and the partisan activities of peak-level DGB and union officials. ${ }^{28}$ DGB and union members pursue interests opposed to other social groups, but they do so within boundaries.

and Dietrich Rueschemeyer (Cambridge University Press, 2002) 295; Charles Taylor, "Modernity and Identity," in Schools of Thought, eds. Joan W. Scott and Debra Keates (Princeton, NJ: Princeton University Press, 2001), 139-53.

24 Frederik Barth, "Introduction," in Ethnic Groups and Boundaries, ed. Frederik Barth (Oslo: Universitaetsforlaget, 1969), 15-17; Katznelson, "Periodization and Preferences," 295.

${ }^{25}$ Brownlie, Principles of International Law, 342.

${ }^{26}$ Theo Pirker, Die blinde Macht: Die Gewerkschaftsbewegung in Westdeutschland (Munich: Mercator Verlag, 1960) vol.2, 77.

${ }^{27}$ Pirker, Die blinde Macht, v.2, 23ff; Kurt Klotzbach, Der Weg zur Staatspartei (Berlin and Bonn: J.H.W. Dietz Nachfolger GmbH, 1982), 250-251.

${ }^{28}$ A partisan Proporz ("proportionality") distributes positions in the DGB executive among Social Democrats and Christian unionists. Lower level DGB and union officials hold Bundestag mandates for various parties, but strong norms prevent members of the DGB Executive and union presidents from representing parties in parliament or government. Both SPD- and CDU/CSU-led governments consult union leaders in selecting individuals for cabinet positions, especially the Minster for Labor and Social Policy, but unionists relinquish union functions while holding such portfolios. See Anton Pelinka, Gewerkschaften im Parteienstaat (Berlin: Duncker \& Humblot, 1980), 95-6, 99, 109-10, 114. 
Institutional boundaries in domestic and international political arenas force individual behavior to conform to higher-level values embedded in social structure. The boundaries of institutions, therefore, reflect conflicts and compromises not only between the members of an institution, but also between the protagonists of different values in society.

Institutions win legitimacy and broader support by reinforcing social values. ${ }^{29}$ By organizing social space and transmitting the hierarchy of societal values through to the level of individuals, institutional boundaries act as a critical part of the "settlements" that prevent societies from disintegrating. This means those interested in supporting and enforcing the boundaries of a particular institution extends beyond actors who participate in or interact with it directly to a broader set of societal actors. To the extent that an institution contributes to the reproduction of social values, the maintenance and enforcement of its rules, particularly its boundaries, become a matter of social stability. They matter not only to members of the institution and those who interact with it directly, but also to society more generally. ${ }^{30}$ This represents the growth of "legitimacy" and may be the result of different processes. ${ }^{31}$ Rationalists stress that institutions perform functions that make them indispensable to the reproduction of values that keep society together. ${ }^{32}$ Sociological perspectives argue that some institutions have symbolic or cognitive value that makes their survival essential to the legitimacy and survival of other institutions in society. ${ }^{33}$ Regardless of its source, this legitimacy provides a reason for even those actors who are not directly affected by its actions to enforce its rules.

A contemporary example arises from the sometimes furious debate over the separation between church and state in the United States. This boundary is often cast as a foundational value of U.S. society, preventing both the establishment of a hierarchy of religions or ideologies within the United States and the state-sanctioned subordination of minority religious views to majority ones. Churches and religions as institutions are deeply socially embedded in this particular fashion in the United States and their limited boundaries are understood within a broader frame of ordering and preserving fundamental societal values.

Similarly, the evolution of DGB "neutrality," described above, is intimately linked to the unionists' desire to support parliamentary democracy in the fledgling

\footnotetext{
${ }^{29}$ Mary Douglas, How Institutions Think (Syracuse: Syracuse University Press, 1986).

${ }^{30}$ Wolfgang Streeck and Kathleen Thelen, "Introduction: Institutional Change in Advanced Political Economies," in Beyond Continuity, eds. Wolfgang Streeck and Kathleen Thelen (Oxford and New York: Oxford University Press, 2005).

${ }^{31}$ Arthur Stinchcombe, Constructing Social Theories (Chicago: University of Chicago Press, 1968), 163.

32 See for example, James Fearon and David Laitin, "Explaining Interethnic Cooperation," American Political Science Review 90 (1996): 715-735.

33 Paul DiMaggio and Walter Powell, "Introduction," in The New Institutionalism in Organizational Analysis, eds. Paul DiMaggio and Walter Powell (Chicago and London: University of Chicago Press, 1991); and W. Richard Scott, Institutions and Organizations, 77.
} 
Federal Republic. Contrary to many unionist hopes, the Adenauer government asserted a doctrine of "parliamentary sovereignty," delegitimizing extraparliamentary pressure (e.g. strikes) for political ends and limiting the ability of unionists to influence policy. ${ }^{34}$ Unionists accepted "parliamentary sovereignty" - and a consequent division of labor that left parties as the representatives of employees' interests in policy arenas and unions as the employees' representatives in labor markets - as the price of stabilizing institutions of West German democracy against subversion. German unions became a "pillar" (Ordnungsfaktor) of the democratic order rather than a "principled opposition" (Gegenmacht), supporting, and supported by, other groups carrying democracy in West German society. ${ }^{35}$ Thus, the examples of separation of church and state in the US and the acceptance of "parliamentary sovereignty" in the FRG demonstrate how institutions acquire legitimacy and broad support in the societies of which they are part because boundaries project "settlements" about societal values over individuals' behavior.

\section{INSTITUTIONAL BOUNDARIES, VARIANCE, AND BEHAVIOR}

The new institutionalisms' neglect of boundaries also blinds them to important effects of institutions on actor behavior. A central focus of historical institutionalists, in particular, has been explaining how actors construct similar institutions - unions, for example-differently in different places. ${ }^{36}$ Likewise, constructivists have sought to explain how variations on the institution of the nation-state affect the nature of inter-state interaction. ${ }^{37}$ Differing institutional structures then become an explanation for variance in actor behavior. The historical institutionalist and constructivist argument about the origins of behavioral variance can be applied to institutional boundaries. Doing so provides insights into behaviors that an exclusive focus on authority relations within institutions might overlook.

These explanations of institutional variance neatly extend to institutional boundaries. Although all institutional boundaries organize social settlements over individual behavior, similar institutions can have different rules that govern their boundaries. Institutions that exist in the same society as well as those that perform

\footnotetext{
${ }^{34}$ This use of the term "parliamentary sovereignty" should not be confused with the use of the term in the context of British politics where it indicates that parliament acts without formal constraint by a written constitution or the acts of previous parliaments.

${ }^{35}$ Eberhard Schmidt, Ordnungsfaktor oder Gegenmacht: Die politische Rolle der Gewerkschaften (Frankfurt a.M.: Suhrkamp, 1971).

36 Kathleen Thelen and Sven Steinmo, "Historical Institutionalism in Comparative Politics," in Structuring Politics, eds. Sven Steinmo, Kathleen Thelen and Frank Longstreth (Cambridge U.K. and New York: Cambridge University Press, 1992), 1-32.

37 John Gerard Ruggie, "Territoriality and Beyond: Problematizing Modernity in International Relations," International Organization 47 (1993); Thomas Risse-Kappen, Cooperation Among Democracies (Princeton: Princeton University Press, 1995); Peter J. Katzenstein (ed.), The Culture of National Security: Norms and Identity in World Politics, 1st ed. (New York: Columbia University Press, 1996); Alexander Wendt, Social Theory of International Politics (Cambridge: Cambridge University Press, 1999).
} 
similar roles in different societies may have different boundaries. For example, the Austrian Trade Union Federation's (ÖGB) statute contains a neutrality clause almost identical to the DGB's, but institutional boundaries permitted complete interpenetration of party and union organizations and direct integration of unions into policy making. ${ }^{38}$ Such diversity is the consequence of the different value preferences that distinguish social "settlements" across societies and "path dependence." 39 Path dependent arguments suggest that events in one time influence future events. Social structure and the distribution of power vary across time and place, pushing individual societies toward particular conflicts, and resolutions of them, and different institutional structures. For example, different distributions of power among social groups might lead to the creation of governance institutions based on representative democracy in one place or authoritarianism in another. Or, to extend the comparison above, differences in the Allied administration of Austrian and German occupation, permitted unions in the former-but not the latter - to exploit their strength in the immediate postwar era to institutionalize their influence in economic policy making. Once in place, however, institutions tend to reinforce certain interests and outcomes, cementing the relationships that led to their structure in the first instance. Thus, institutions project the impact of particular conflicts, distributions of power, and social choices across time. This same process produces variance in institutional boundaries. Because they come into being under different circumstances, the boundaries of institutions look very different from one another.

Existing analyses provide an explanation for why institutional boundaries vary, but-so far-they have not examined how they vary. We suggest that, most simply, boundaries vary in their permeability, whether they permit outside actors to exercise influence within an institution and whether they permit actors within the institution to wield influence in other arenas. Does society condone, through particular boundary regulations, the influence of some actors or institutions on the decision making of other institutions or not? How are the authority relations inside the institution related to the hierarchies that govern other institutions and society itself? Do boundary regulations create privileged channels of influence for some types of actors or do they seek to limit them, forcing contests to influence institutional decision making into more transparent or competitive arenas? As a concrete example, one might consider the different means of integrating markets across national boundaries: managed trade, harmonization and mutual recognition. ${ }^{40}$ These questions are not new, but the concerns of an "old" institutionalism of Montesquieu and Madison. This "old" institutionalism recognized explicitly that institutional boundaries are mechan-

\footnotetext{
38 Pelinka, Gewerkschaften im Parteienstaat, 104; Fritz Klenner, Das Unbehagen in der Demokratie (Vienna: Verlag der Wiener Volksbuchhandlung, 1956), 54ff.

${ }^{39}$ Paul Pierson, "Increasing Returns;" James Mahoney, "Path Dependence in Historical Sociology," Theory and Society 29 (2000): 526-7.

${ }^{40}$ Miles Kahler, "Trade and Domestic Differences," in National Diversity and Global Capitalism, ed. S. Berger and R. Dore (Ithaca, NY: Cornell University Press, 1996), 300.
} 
isms that enforce societies' preferences over individual behavior, elevating some values while subordinating others. While the "old" institutionalism focused on the boundaries of formal governmental institutions, however, we see the problem of boundaries extending wherever there are institutions. Classically, four mechanisms have permitted actors to influence decision making across institutional boundaries: 1) formal rules that specify such influence (often backed up by state power); 2) control over resources critical to an institution; 3) the personal union of decisionmaking roles in different institutions; and 4) ideological affinity. Boundaries that proscribe such mechanisms are relatively impermeable, such as anti-trust laws that prohibit collusion among firms. Those that condone them are more permeable, such as the overlapping jurisdictions in federal systems.

The relative permeability of institutional boundaries touches on many types of behavioral outcomes. Boundary regulations have perhaps their greatest impact on the coordination of decision making between institutions and organizations. Between functionally differentiated institutions, permeable boundaries may permit coordination as between the "pillarized" institutions of plural societies. Impermeable or solid boundaries between interest groups and parties, on the other hand, may enforce a division of representational labor between them, such as between parties and unions in postwar West Germany. Between undifferentiated organizations, permeable boundaries may invite collusion while solid boundaries enforce competition. In the structural realist conception of states as unitary actors, bounded by sovereignty, these actors are functionally the same as their core purpose is vying for survival in an anarchic system. ${ }^{41}$ Boundary regulations may also shape flows of information. The price mechanism of the mythical, perfectly competitive market relies on borders between firms that guarantee all equal access to information. Conversely, the success of collusion often depends on the maintenance of opacity around decision making. These are areas of behavior shaped as much by the limitations placed on authoritative rules as by the rules themselves.

We have focused on the stabilizing and reproductive elements of institutional boundaries here, though we recognize that variance in institutional boundaries also facilitates institutional change and can undermine stability. Permeability in particular opens the possibility for boundary shifts that may significantly alter the institution itself and its internal relations, but also its relations with external institutions. ${ }^{42}$ These boundary changes in turn can trigger societal change. Attention to how a boundary gets drawn or the nature and outcome of boundary disputes will bring more attention to how such changes can feed back into society to alter fundamental institutions and values as well as the overall organization of society. Small changes in institution-

\footnotetext{
${ }^{41}$ Waltz, Theory of International Politics, ch. 4.

${ }^{42}$ For an empirical example of permeability in the boundary of sovereignty leading to broader institutional change, see Anne L. Clunan, "Redefining Sovereignty: Humanitarianism's Challenge to Sovereign Immunity," in Negotiating Sovereignty and Human Rights: Actors and Issues in Contemporary Human Rights Politics, ed. Noha Shawki and Michaelene Cox (Farnham, UK: Ashgate, 2009), 7-26.
} 
al boundaries can ultimately have large societal effects, as small changes in the drawing of jurisdictions can have reverberations for overall societal order. This is an issue we raise here primarily with an eye to further research, as our main focus has been on how boundaries matter and how they vary.

\section{CONCLUSION}

We have sought to highlight how the nature of, and change in, the boundaries of discrete institutions has important consequences for broader social organization and order. Institutional boundaries deserve attention because they are what structure - in very different ways - the amount and ease of access between institutional domains. In defining that access, they can serve to reproduce or alter institutions.

The nature of boundaries determines whether, and which, actors are able, or unable, to operate legitimately within, and across, institutional jurisdictions. Boundaries transmit social and institutional rules internally, as in the interactions between unions and political parties and between sovereign governments and their citizens, but they also transmit social rules between institutions, as in the preservation of sovereign immunity. ${ }^{43}$ In these ways, boundaries can protect institutions and contribute to institutional survival and continuity. They also organize and stabilize social orders, fostering collective action in some realms and regulating conflict in others.

We have also suggested that the creation of boundaries, or their change, can reverberate throughout other institutions in society, shaping their relations and the overall degree of institutionalization of the values on which a society is founded. Boundaries transmit social values and roles to institutional and societal actors and individuals. For these reasons, we think that more attention needs to be paid to the boundaries of institutions. Without understanding how these borders come into being and what the consequences of their creation and alteration are, we are likely to miss how the nature of a boundary or its change can ripple through society, potentially producing major institutional as well as societal change.

An important focus of future research is the way in which boundaries can vary and the consequences of that variance. We suggest that the variance in the permeability of boundaries is particularly worthy of further research for three reasons. First, the permeability of an institution's boundaries is likely to have significant impact not only on relations within, and between, institutions, but also on the overall pattern of power and authority within society. This is because permeability determines which actors have power and influence within, and across, institutions. Second, the permeability of boundaries determines the likelihood of political struggles over those boundaries and therefore the likelihood of institutional change. Third, as a consequence, permeable boundaries are more likely to be associated with fundamental transformation of the values underpinning society. We suggest that the tools of

${ }^{43}$ Clunan, "Redefining Sovereignty." 
historical institutional and constructivist analysis are particularly appropriate for understanding when, and how, boundaries come into being, how they facilitate collective action among like, and unlike, actors; and, more broadly, for understanding the relationship between institutional and social change.

John Leslie

john.leslie@vuw.ac.nz

Anne L. Clunan

alclunan@nps.edu 